\title{
Qualitative Case Study: Building an Online Learning Community
}

\author{
Vera Queiroz $^{1 *}$, Marcel Simonette ${ }^{2}$, Edison Spina ${ }^{3}$ \\ ${ }^{I}$ Free Consultant, Brazil \\ ${ }^{2}$ Universidade de São Paulo - Dep. of Computer and Digital Systems Engineering - PCS \\ ${ }^{3}$ Universidade de São Paulo - Dep. of Computer and Digital Systems Engineering - PCS
}

*Corresponding Author: Vera Queiroz, Free Consultant, Brazil

\begin{abstract}
The present study is a qualitative case study of an experimental basic-English online course with emphasis on the development of writing and reading skills. This course was offered to students from different countries, whose native language was not English and was delivered simultaneously by two teachers of English residing in distinct countries. The study attempted to verify whether the students in the course, which adopted a teaching and learning collaborative/communicational methodology, became a "learning community" as per the characteristics described by several theoreticians from which we selected the following: students' common interests in attending the course: empathy, collaborative sociability and time of exposure in the group. The data were collected from the course when it was given. Data consisted of digital documents (such as students' email, email exchanged between the teachers, questionnaires, registers of students' participation in the discussion forum, chat sessions and individual, peer and collective task performance), and the participant observation of the teacher/researcher throughout the course. The theoretical framework was based on communicative theory, the collaborative learning approach, the theoretical framework on virtual learning communities and on online courses. The data showed that the online course achieved its objective of promoting collective learning. The data also confirmed that a learning community was created and maintained.
\end{abstract}

Keywords: Collaborative Learning; Virtual Learning Environment; Online Collaborative/Communicational Methodology; Experimental English Online Course; Online Basic English-As-A-Foreign-Language Course.

\section{INTRODUCTION}

The transformations generated by the globalization phenomenon, and incremented by technological resources, give rise to meaningful changes in the economic, social, philosophical, political, cultural and educational panorama of contemporary society.

In general, the traditional model of Education - teacher centered - is no longer effective. Therefore, new models have been tried, as is the case for the collaborative/communicational model, centered on the interaction between teacher/student and student/knowledge. This model has its theoretical basis in constructivism (Piaget, 1967 \& Vygotsky, 1991) whose principle is that the exchanges of knowledge among individuals are decisive for the intellectual development of the human being. Communication Pedagogy also served as theoretical basis for this model. According to Penteado (1999), researcher of Communication Pedagogy, this educational science conceives of teaching as a multi-way communication process, whose specificities are explicit in the necessary relations with knowledge and give power to all interlocutors to express themselves.

With the advance of Information Communication and Technologies (ICTs), we are faced with new possibilities and challenges in the process of teaching and learning. However, the challenge to establish an educational method that stimulates collaborative/participative practices in which teachers and students learn together, even though they are physically separated by space and time, still exists. It is a way of thinking about Education to try to make it more productive and able to deal with teaching and learning in virtual environments. These environments would become "spaces" of development of cognitive and non-cognitive capabilities between teacher and learners and the latter among themselves.

According to Azevêdo (1999), "the problem of student's passivity is the result of a pedagogical model the students were adapted from pre-school". In this model, according to the author, "the 
student is seen fundamentally as a receptor of the content, whose task is to assimilate and reproduce, but almost never to problematize, analyze, reflect, that is to discuss."

With this problem in mind, it is possible to understand the difficulty learners have to work together, to dialogue/interact amongst themselves and to 'dialogue' with the knowledge and information they can access from different sources, and the teacher's challenges to engage him/herself and the students in a real collaborative teaching-learning process.

As the methodologies adopted in online courses are still being worked out, only through studies and research on joint performances of teachers and students in online teaching situations would it be possible to evaluate the best methods to use in this type of teaching.

For the construction of a teaching-learning methodology that is established gradually and with the collaboration of all (teacher and students), it is up to the educator to create conditions that elicit the participation of the students both amongst themselves, with the teacher, and with knowledge, in the learning process.

The first condition for a changing process, looking for new ways of teaching and learning, is that the teacher must aim at freedom to experiment and must not be afraid of breaking pre-established, oldfashioned rules, and the bureaucratic and institutional pressures that limit autonomy and teacher innovation. This condition is essential to better contribute to training autonomous individuals, forming true citizens who are creative and critical - issues that are essential to life and participation in the contemporary world.

To try to create a non-authoritarian or imposing 'culture', that is, a 'culture' of participation, collaboration, trust and commitment among the members of the group - online students and teacher -, Moran (2000, p.16) warns:

[...] we can only educate for autonomy, for liberty with fundamentally participative, interactive, liberating processes that respect the differences that motivate/supportoriented by free persons and organizations.

Reflecting upon this 'culture', the present work was an experimental pedagogical proposal of a free basic English online course with focus on the development of writing and reading skills using a collaborative/communicational teaching-learning method. Personal and social values (such as the exercise of autonomy, sociability, social integration, and mutual respect) were developed to establish a greater involvement both amongst the participants and with English language knowledge. This work also tried to verify whether the basic English course would become a learning community.

In this scenario, the provocative questions of this research were

- How to motivate students towards a more authentic and autonomous personal relation with knowledge?

- How to develop individual and collective attitudes necessary for optimizing a more participative, collaborative and dynamic learning in virtual environments?

- How to create a 'culture' of collaborative interaction between teacher and student and the latter among themselves?

- Is it possible for an online course, in which interactions are stimulated, affective and social bonds built and established between individuals (that may never meet face-to-face) become an important 'step' for the development of a virtual learning community?

\section{THEORETICAL FrAMEWORK}

To give support to the research, a view of virtual community, virtual learning community \& online course were considered. The literature is vast. Many authors have been dealing with these subjects for some time, among them: Oliveira, 2015; Chakraborty \& Nafukho, 2015; Heemann \& Leffa, 2013; Palloff \& Pratt, 2013 \& 1999; Lévy, 1999 \& 1998 and Rheingold, 2000.

For Lévy (1998), a virtual community is associated with feelings that permeate its organization. When dealing with the theme, the author talks mainly about the characteristics that can be observed in these communities: what brings the members together and the social relations that are established: the problems, conflicts, passions, and friendships. Even though conflicting interpersonal relations that 
may occur in virtual communities seem negative at first sight, they are considered positive by Palloff \& Pratt (1999). Discussing the conflict in virtual communities, these authors say that "[...] it is necessary in order to achieve group cohesiveness and intimacy..." (p. 27). Thus, it is possible to perceive that the resolution of the conflicts generated in virtual environment promotes, enriches and consolidates the relations among the virtual community members.

Laister \& Kober (2002) state that the great challenge in building a virtual learning community is to establish and give support to a "new learning culture" where communication happens in a 'horizontal' way and is effective among individuals involved in the learning process.

A basic and fundamental difference between an online course and a community is that a course supposes a teacher, and a community does not. Thus, there is a difference in a course, which is marked by the different roles of its component actors: teacher and students. Another difference is that a community implies bonds of sentiment (Feenberg, 1989; Palloff \& Pratt, 1999) that do not always happen in an online course.

Moran et al. (2000) state that the way the teacher relates to the students is fundamental to pedagogical success; thus, it is essential that emphatic bonds are established from the very beginning. An empathic relationship (as I perceive it) is generated by a subjective affinity that leads the individuals to desire to interact and to communicate, that is, to establish a sharing relationship that can be stimulated by pedagogical practices - first at the level of sharing common interests, then unfolding in affective bonds.

Another important bond to be considered is sociability. Adler (1967, p. 65) supports this argument, stating that empathy and sociability are associated/related one with the other. However, it cannot be denied that a difficulty permeates the creation of affective and social bonds among the members of a group, especially if it gathers individuals that never meet face-to-face.

With technology, the concepts of class, space, time, individuality and collectivity should be reviewed, as it promotes new ways for teachers and learners to "be" together, even if they are physically separated by geographical distance. Classes are no longer limited by bounderies of space and time, and the concepts of individuality and collectivity find support in Delors (1996). This author presents for A UNESCO Report to the International Commission on Education for the XXIst century an educational proposal based on four pillars: 'learn to know', 'learn to do', 'learn to be' and 'learn to live' - essential aspects for learning in the new century.

From Delor's proposal, it is possible to realize the new roles the students and the teacher are starting to play. The students become responsible for their own learning process and are required to learn to work collaboratively with their classmates and share their knowledge.

Simultaneously, the redefinition of the role of the teacher points to a refining of his/her professional competences that go beyond the specific content domain of his area of knowledge, practice, study and specialization; the teaching procedures and the evaluation models. The teacher needs to develop ways to awaken the students' interest, motivation, emphatic attitudes and collaborative sociability, especially if he/she plans to try to build, develop and maintain a learning community.

When setting up a course, motivation is also a keyword. According to Lumsden (1994), motivation is related to the student's desire in participating in the learning process, and subjacent reasons for his/her involvement in academic activities. Arguing about motivation in the acquisition of English language, Rivers (1997) states that the degree of motivation (strong or weak) always exists and that the teacher has to unveil the device that triggers it in each individual and to channel it so that language acquisition reaches a greater scale.

The theoretical background intends to be the basis for the reflection about the experimental online course proposed and the possibility of building, developing and maintaining a virtual community.

\section{Method}

The methodology used for collecting the data for this research and the way the data were analyzed is based on the assumptions of qualitative research, as it is seen by Chizzotti (1991, p. 79)

[...] The qualitative approach is based on the principle that there is a dynamic relation between the real world and the subject, a live interdependence between the objective 
world and the subjectivity of the subject. Knowledge is not reduced to a list of isolated data, connected by an explanatory theory; the subject-observer is integral part of the knowledge process and interprets the phenomena giving them a meaning

In qualitative research is

In social interactions, (that) individuals forge anticipated behaviors and act by the behaviors expected of others (actor theory). Research cannot be the product of an observer outside the meanings that individuals attribute to their acts; on the contrary, it must be the unveiling of the social sense that individuals construct in everyday interactions (CHIZZOTTI, 1991: 80).

And yet, in this type of research, the author warns us to the fact that:

[...] The identification of the problem and its delimitation presupposes an immersion of the researcher in life and context, in the past and in the present circumstances that condition the problem. They also presuppose a practical sharing of the experiences and perceptions that subjects have of these problems to discover the phenomena beyond their immediate appearances. The delimitation is done, therefore, in a field where the initial question is explicit, revised and oriented from the context and the information about the people or groups involved in the research (p.81)

The research can also be characterized as participant observation and case study. The participant observation is justified by the exploratory nature of the work about the phenomenon that is the online teaching.

In the development of this proposal, I assumed the role of teacher/researcher to be able to experience the collaborative/communicational learning facilities, difficulties, properties, possibilities and limits of a free online course using a pedagogical perspective which included the process of both learning to be a teacher and learning to deal with online students.

According to Chizzotti the participant observation "is obtained by means of direct contact of the researcher with the observed phenomenon, to gather the actors' actions in the natural context, from his perspective and points of view" (p.90), what supports the means used for collecting data.

The option for a case study is due to the fact that this research might contribute with reflections about the teacher/researcher's actions and interventions in the online environment interested in making the students co-responsible for their learning process and in having conditions to build a true virtual learning community.

The case study of this research is delimited in time and space by a singular group follow-up. According to Lüdke \& André (1986, p. 17):

The case study is a study of a case, being simple or specific, or complex and abstract.

The case is always delimited, with its contours clearly defined in the course of the study. The case can be similar to others, but it is at the same time distinct, because it has a proper, singular interest.

Each stage of the course was evaluated and re-structured, aiming at improvements and re-adjustments to its objectives. This allowed a course planning in a procedural way and better served the students in their linguistic needs and expectations also (re)elaborated throughout the course. The initiatives, procedures and occurrences between teachers and students; student/student, and with the basic knowledge of the language were registered.

Being a one-off case, as clarified by Lüdke \& André (op cit, p.23), "the case study assumes that the reader will use this tacit knowledge to make generalizations and develop new ideas, new meanings, new understanding." This exempted the researcher from elaborating generalizations. However, it required a careful analysis of the circumstances of the course in focus, which could enable the reader to compare teaching situations the teacher/researcher had been involved in.

\section{RESEARCH CONTEXT}

\subsection{Subjects}

The course started with 20 students, 8 males, and 12 females and lasted 7 months, along which there was a student turnover, with permanence of 3 throughout the course. 
The course was taught jointly with a colleague, also a teacher of English as a Foreign Language (EFL), born and living in Argentina who volunteered to help.

While the teacher from Argentina was responsible for the didactic activities, I was in charge of the design of the course from planning to evaluation and the organization and management of the virtual environment.

The linguistic level of the students was not homogeneous; some were false beginners. $50 \%$ of the students came from the European continent, 30\% of the Asian continent, and 20\% of Latin America. Although there is no information about the age of the students, $80 \%$ were adults with higher education. Of the $85 \%$ who reported on their ability to use the computer, the majority declared to have intermediate and advanced knowledge. Asked about how they have learned about the course, 50\% declared searching the Web.

\subsection{Scenario}

To carry out the basic English course, the LMS chosen was Blackboard for it was a user-friendly platform and had the necessary communication and management tools for the experiment.

\subsection{Data collecting}

The research data were collected from the teacher/researcher 's participant observation throughout the course and from digital documents.

The use of digital documents as a research tool was based on Lüdke \& André (1986, p. 38): "documentary analysis may constitute a valuable technique approach to qualitative data, by supplementing the information obtained via other techniques $[\ldots] "$

The list of digital documents was:

- a 7 open question questionnaire (before the course began) to gather information to characterize the group of students;

- a 6 open question questionnaire (at the end of the course) to get feedback about the course and students' interest in new courses;

- email exchanged between the teachers to discuss didactic procedures and to strengthen relationship between the online professionals;

- email exchanged with the students for language help and basic technical support using the LMS;

- individual, peer and group tasks to check effectiveness in improving the language reading and writing skills and in promoting collaborative learning;

- chat sessions between the teachers to evaluate the practices used and the pedagogical method chosen;

- registers of students' participation in forum sessions to check reading and writing skills improvements and to promote intra and interpersonal attitudes that could serve as indicators of a virtual collaborative learning community.

All the data were then organized so that the researcher could proceed to their management.

\subsection{Data management}

The data were analyzed and interpreted according to the theoretical vision that based the work in the effort to answer the research questions.

The data were organized in two categories. The first one dealt with collaborative/communicational teaching and learning and included the analyses of individual, peer and collective activities; the students' responses to the activities; the joint teaching procedures, and the teacher's and students' resulted learnings.

The second category was created with the purpose to verify fundamental indicators of building a learning community from an online course, and to try to answer the research question about this 
theme. From the characteristics of a virtual community and the levels of students' desires to act and interact with the classmates, pointed by the several authors studied, the fundamental elements to be considered were:

- motivation and common interests (desire);

- $\quad$ signs of emphatic relations;

- commitment with the group;

- time of exposure in the group.

\section{RESUlts}

This case study points some properties that are relevant to teaching in online learning courses:

- Teachers joint work (whenever it happens): teachers must work considering the importance of theoretical-methodological principles from the very beginning of the work. It is necessary to apprehend the educational role of 'error' in the collaborative/communicational teachinglearning process; differently from what happens in the traditional teaching approach, 'error' is not considered a stigma but a "learning propeller spring" (KRASILCHIK, 2001; PENTEADO, 2002).

- Teachers \& learners acceptance: It is a consequence of the previous property. The theoretical-methodological principles are the basis for teacher's and learners' relationship; for the acceptance of each other as partners or co-responsible for the teaching-learning process. This relationship exposes teachers to unforeseen learning situations that could be challenges for searching for new learning approaches and methods. Learners, on the other hand, are stimulated to search for different types of sources of knowledge and to share them with their classmates. The teacher is no longer the only source of knowledge.

- Teachers' involvement: Knowledge is organized in a horizontal and democratic way. Teachers are facilitators who help students overcome their difficulties. There is no charge for students" participation, which is common in traditional teaching. "Charges" become "invitations" for participation.

- Language role: In any foreign language course, the language itself has an important role as a communication tool. Using the collaborative/communicational methodology in the course, the teacher is no longer the only students' interlocutor. Students are stimulated to communicate and interact with their classmates and to express themselves in an understandable way in different written situations. In online courses, written language becomes even more important, as body language and gestures are not used as a mechanism for transmitting meaning.

The teacher should be aware of these properties and to reflect upon them whenever delivering a course that aims to be engaging and motivational to students.

\subsection{Teaching Practices}

Teaching practices related to the organization of online courses should consider learners' previous knowledge. This is especially relevant to the organization of a language course. It is necessary to have an initial questionnaire:

- To identify learners' past language learning experiences to build "bridges" between "past learning methods" and the method to be used in the new course.

- To identify knowledge about the virtual environment. The fact that students claim to have a computer intermediate or advanced knowledge and to know to navigate on the Web does not mean familiarity with any LMS (Learning management system).

- To identify foreign language level. In the questionnaire, questions about the students' expectations about the course can provide this information, as the learner has to express himself/herself in the foreign language.

The collaborative/communicational method used in the course showed the importance of individual work before collective work. Self-correction and self-evaluation contributed to the exercise of 
autonomy as students were encouraged to "learn to learn" and "learn to do". Similarly, the collective work with multiple learning partners in sharing situations from different knowledge sources contributed to the exercise of alterity which is related to "learn to be" and "learn to live (DELORS, 1996).

\subsection{Building Virtual Learning Communities}

The case study showed four meaningful variables for building a virtual learning community from an online course. These variables are: desire, empathy, collaborative sociability and time of exposure to the group.

- Desire constitutes the "key element" that gathered the learners around the common interest of learning or improving a foreign language (in the study presented - EFL).

- Empathy (share of desire) and collaborative sociability (maintenance of desire) created between teachers and learners are necessary elements to achieve the goal of building a learning community. It must be highlighted the role of the collaborative/communicational pedagogy to promote participative and sharing attitudes.

- Time of exposure to the group is important to try to establish the affective and social bonds, trust and desire to interact and collaborate in and with the group and to arouse the feelings of belonging (RHEINGOLD, 2000; PALLOFF \& PRATT, 1999).

\section{CONCLuSion}

The results of this work serve as basis for new researches on free online courses and on virtual learning communities. Also, it is expected that the results become part of the studies of initial foreign language teacher training, especially for the teachers who want to work with technology.

This case study shows the necessity to continue the research to answer questions such as: How long should an online course take to be considered ideal? Should the course be divided into modules? How many? What are the requirements in terms of time spent by a teacher to organize and deliver online courses based on collaborative/communicational methodology? What is the ideal number of students coming from different cultures and speakers of different languages that can join a basic English online course that uses collaborative/communicational methodology?

The author hopes that desire, share of desire, and maintenance of desire, considered in this research as fundamental for building a virtual learning community be further studied and discussed by the research community.

The great challenge of this educational proposal is to gather in an English language course students from different geo-cultural experiences, spatially distant from each other. Therefore, the possible contributions of intercommunication between these students are only made possible by the cyberspace and the foreign language.

\section{ACKNOWLEDGMENTS}

This work was partly supported by the Society and Technology Study Centre (or, CEST - Centro de Estudos Sociedade e Tecnologia, in Portuguese) at the Universidade de São Paulo.

\section{REFERENCES}

[1] ADLER, A. A. A Ciência da Natureza Humana. Trad. Godofredo Rangel \& Anísio Teixeira. 6. ed. São Paulo: Companhia Editora Nacional.

[2] AZEVÊDO, W. 'Muito Além do Jardim de Infância - O desafio do preparo de alunos e professores online'. In: VI CONGRESSO INTERNACIONAL DE EDUCAÇÃO A DISTÂNCIA, 1999, Rio de Janeiro. Retrieved April 132018 from <http://educacaoonlineparatodos.blogspot.com.br/2011/07/muito-alem-dojardim-de-infancia-o.html>.

[3] CHAKRABORTY, M. \& NAFUKHO, F. M. (2015) 'Strategies for Virtual Learning Environments: Focusing on Teaching Presence and Teaching Immediacy'. Internet Learning: Vol. 4: Iss. 1, Article 2. Retrieved April 102018 from <http://digitalcommons.apus.edu/internetlearning/vol4/iss1/2>.

[4] CHIzzOTTI, A. Pesquisa em ciências humanas e sociais. São Paulo: Cortez, 1991. (Biblioteca da educação; ser. 1, Escola, v.16.)

[5] UNESCO. (1996). DELORS, J. et al. The four pillars of Education. In: Learning: The Treasure Within. Retrieved April 132018 from <http://unesdoc.unesco.org/images/0010/001095/109590eo.pdf〉. 
[6] FEENBERG, A. 'Distance Learning: Promise or Threat?' [a slightly longer version of a paper published in Crosstalk, winter, 1999]. Retrieved April 132018 from <https://www.sfu.ca/ andrewf/books/Distance _Learning_Promise_Threat.pdf

[7] HEEMANN, C. \& LEFFA, V. J., 2013. 'Educação a Distância: A formação de Comunidades Virtuais de Aprendizagem'. Pelotas: EDUCAT (Editora da Universidade Católica de Pelotas.

[8] KRASILCHIK, M. As Relações Pessoais na Escola e a Avaliação. In: CASTRO, A. D. de; CARVALHO, A. M. P. de (orgs.). Ensinar a Ensinar. Didática para a Escola Fundamental e Média. Rev. Janice Yunes. SP: Pioneira Thomson Learning, 2001. cap. 9, p. 165-175.

[9] LAISTER, J. \& KOBER, S. 'Social Aspects of Collaborative Learning in Virtual Learning Environments'. Networked Learning Conference, 2002. Lancaster University and University of Sheffield. Retrieved April 132018 from <http://cmapspublic2.ihmc.us/rid=1182801989765_1087355552_6317/Laister_Kober _2002.pdf >.

[10] LÉVY, P. O que é o Virtual. 2. reimp., Trad. Paulo Neves. São Paulo: Editora 34 Ltda, 1998.

[11] Cibercultura. 1.ed. Trad. Carlos Irineu da Costa. São Paulo: Editora 34, 1999. (Coleção TRANS).

[12] LÜDKE, M.; ANDRÉ, M. E. D. A. Pesquisa em educação: abordagens qualitativas. São Paulo: EPU, 1986.

[13] LUMSDEN, L. S. 'Student Motivation To Learn'. ERIC DIGEST, n. 92, 1994. Retrieved April 132018 from <https://www.ericdigests.org/1995-1/learn.html>.

[14] MORAN, J. M; MASETTO, M.; BEHRENS, M. Novas tecnologias e mediação pedagógica. Campinas, SP: Papirus Editora, 2000. (Coleção: Papirus Educação).

[15] OLIVEIRA, G. P. de. 'Comunidades, Comunidades Virtuais, Comunidades Virtuais de Aprendizagem'. Revista Eletrônica de Tecnologia e Cultura (RETC). Edição 16a, abril 2015, p. 95. Retrieved April 102018 from <http://www.fatecjd.edu.br/aviso/edicoes/16ed.pdf>.

[16] PALlOFF, R. M. \& PRATT, K. The Lessons from the Virtual Classroom: The Realities of Online Teaching. S.Francisco: Jossey-Brass Publishers, 2013.

[17] _. Building Learning Communities in Cyberspace: Effective Strategies for the Online Classroom. S.Francisco: Jossey-Brass Publishers, 1999.

[18] PENTEADO, H.D. Comunicação Escolar: Uma Metodologia de Ensino. São Paulo: Ed. Salesiana, 2002.

[19] _ Televisão e Escola: Conflitos ou cooperação? 2. ed. São Paulo: Cortez, 1999.

[20] PIAGET, J. Capítulo VI - Os fatores sociais do desenvolvimento intelectual. In: Psicologia da Inteligência. Trad. Egléa de Alencar, Rio de Janeiro: Editora Fundo de Cultura S. A., 1967.

[21] RHEINGOLD, H. The Virtual Community: Homesteading on the Electronic Frontier. Publisher: Mit Press, 2000.

[22] RIVERS, W. M. (1997) Principle 1.: 'The student is the language learner. In: Principles of Interactive Language Teaching. Retrieved March 222018 from <http://www.edevaluator.org/rivers/10principles - 0. html>.

[23] VYGOTSKY, L. S. A formação social da mente: o desenvolvimento dos processos psicológicos superiores. COLE, M. et al. (orgs.). trad. José Cipolla Neto, Luis Silveira Menna Barreto, Solange Castro Afeche. 4.ed. São Paulo: Martins Fontes, 1991.

\section{AUTHOR'S BIOGRAPHY}

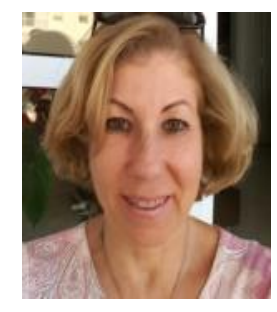

Vera Queirozislicenciate in Languages, Translator and Interpreter from Faculdade Ibero-Americana de Letras e CiênciasHumanas (1977); Master's degree in Applied Linguistics from Pontifícia Universidade Católica de São Paulo (1986) and a Ph.D. in Teaching, Teaching Theory and School Practices from Universidade de São Paulo (2005). She was a member of specialists' commission for technical support and studies in distance education for the State of São Paulo Education Board (ConselhoEstadual de Educação). She has worked as a teacher in language institutions and as a consultant at the Lemann Foundation. While working at the Brazil-US bi-national center in São Paulo, she took part among other assignments in examining committees assessing candidates' proficiency in the English language for graduate programs in the University of São Paulo Law School. She was invited to join the E-mundus group where she was responsible for the edition and publication of Wikieducator E-mundus Brazil. She is a consultant in Education and has amassed experience acting in the following areas: EAD, internet, education, technology, LMSystems, online teaching and learning. At present she is a collaborator with the CEST (Centre of Studies, Society and Technology) of the Universidade de São Paulo 


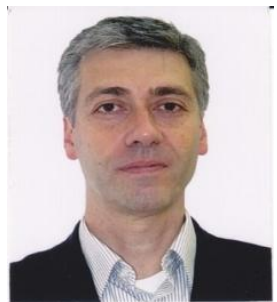

Marcel Simonette holds a degree in Electrical Engineering (1991), an M.Sc.in Electrical Engineering (focused on System Engineering at Sociotechnical Systems - 2010), and a Ph.D. in Electrical Engineering (focused on Human Factors in Software Engineering - 2015); all his titles were obtained at Universidade de São Paulo (USP), Engineering School. He is a researcher in the postdoctoral program of the Engineering School of the University of São Paulo; the research topic is Complexity in Engineering Projects. Also, he works as a researcher at the Society and Technology Study Center (or, CEST - Centro de Estudos Sociedade e Tecnologia, in Portuguese)at USP. His research areas are the following: Software Engineering, Requirements Engineering, System Engineering, and Sociotechnical Systems.

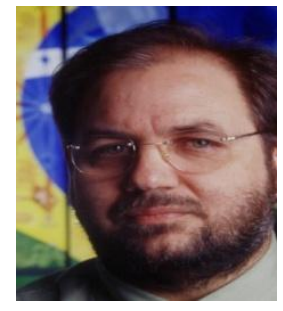

Edison Spina is Ph.D. in Computer Engineering by the Polytechnics School of the University of São Paulo (EP-USP); Auditor Leader ISO 9000 (1995); M.Sc. in 1990 (EP-USP) and Electronic Engineer in 1981 (EP-USP); Freelance Advisor in Electromagnetic Interference and Compatibility (1987), Quality and Management of Projects (1998); Director of Antares Eletrônica Ltda. (industry, 1986-2000), Manager for Projects at the Foundation for Engineering Technological Development - FDTE, Electronic Security Systems Analyst (LCA and GAS / PCS); Assistant Lecturer with the Department of Computer Engineering and Digital Systems - PCS (EP-USP) since 1988; Member of the Knoma (Laboratory of Engineering of Knowledge); Coordinator of the Study Center Society and Technology of USP; Council Member of the Committee of Sciences and Technology of OAB (Brazilian Bar Association); Coordinator of the Brazilian Teams of European Projects INSTINC (FP6), BELIEF (FP6), BELIEF 2 (FP7), VertbrALCUE (Alfa3), eMundus and SMART2 (Erasmus Mundus); Member of the Committee for International Relations of the Polytechnic School (EP-USP); Advisor of the Executive Board of the Menon Group (Brussels).

Citation: Vera Queiroz, Marcel Simonette, Edison Spina. "Qualitative Case Study: Building an Online Learning Community " International Journal on Studies in English Language and Literature (IJSELL), vol 6, no. 5, 2018, pp. 37-45. doi:http://dx.doi.org/10.20431/2347-3134.0605006.

Copyright: () 2018 Authors. This is an open-access article distributed under the terms of the Creative Commons Attribution License, which permits unrestricted use, distribution, and reproduction in any medium, provided the original author and source are credited. 